\title{
IMMUNOCYTOCHEMICAL DEMONSTRATION OF APPEARANCE OF CALCITONIN AND CALCITONIN GENE-RELATED PEPTIDE IN CULTURED C-CELLS DERIVED FROM RAT EMBRYOS
}

\author{
ICHIRo NishiYama and Tomoko FuJII ${ }^{1}$ \\ Department of Pharmacology, Teikyo University School of Medicine, Itabashiku, Tokyo 173, Japan
}

\begin{abstract}
Prenatal development of rat thyroid C-cells was immunocytochemically investigated in culture. Immunoreactivities for calcitonin (CT) and CT gene-related peptide (CGRP) were used as the markers of C-cell differentiation. The thyroid glands at various gestational ages were enzymatically dispersed and cultured in Dulbecco's modified Eagle medium supplemented with $5 \%$ fetal calf serum and $4 \%$ rat embryo extract. In the dispersed thyroid cells of day 14 embryos, CT- and CGRP-immunoreactive cells appeared after 2 days of incubation in 4 cases out of 7 independent experiments. CT- and CGRP-immunoreactive cells appeared without exception in the dispersed thyroid cells of day 15 or later stages of embryos. We have succeeded in establishing the culture condition under which C-cell precursors taken from the embryos as early as day 14 initiate the synthesis of CT and CGRP. These findings suggest that one of the key events participating in C-cell differentiation takes place at day 14 in the rat embryo.
\end{abstract}

C-cells in the thyroid gland of mammalian species produce and secrete calcitonin (CT). CT is a polypeptide hormone consisting of 32 amino acids, and exhibits hypocalcemic action. Besides CT, C-cells produce several biologically active peptides such as CT generelated peptide (CGRP) (15), somatostatin (12), gastrin/cholecystokinin-like substance (7) and, in C-cell line, neurotensin (17). Moreover, the proportion in which C-cells contain these peptides depends upon both the species of animals $(4,6)$ and their ages $(1$, $5,7)$.

C-cells possess paraneuronal characteristics

${ }^{1}$ To whom correspondence should be addressed and have been grouped by Pearse in APUD (amine precursor-uptake and decarboxylation)-series (13). Extensive studies by Le Douarin and her co-worker, by using chickquail allograft technique, revealed that the C-cells originate from the rhombencephalic neural crest (8). Neural crest origin of the C-cells was also confirmed in the rodent by Pearse and Polak with a cytochemical marker system (14).

Although the ontogeny of CT and CGRP was immunohistochemically investigated in several species of animals $(5,11,16)$, the mechanism by which the neural crest cells differentiate into the C-cells remains to be elucidated. It is of great interest when and how the synthesis of these peptides is initiated at the transcriptional level. One approach to 
solve this question is to establish in vitro system in which neural crest cells become to exhibit some, preferably all, of the C-cell properties. For this purpose, fundamental experiments are needed because little or no information is available about the culture of the embryonic thyroid C-cells. In this study, appearance of CT and CGRP was immunocytochemically- examined in cultured thyroid C-cells derived from rat embryos at various gestational ages.

\section{MATERIALS AND METHODS}

\section{Animals}

Wistar-Imamichi rats were kept on a cycle of $14 \mathrm{~h}$ light (0600-2000) and $10 \mathrm{~h}$ darkness, and were fed a commercial diet (Oriental Yeast). A female rat was caged with a male in the evening of the proestrus and the day on which sperm were found in the vaginal smear was designated as day 0 of pregnancy. The embryo at day $\mathrm{X}$ of gestation was designated as G-X embryo. Embryos at different gestational ages (G-14-G-18) were taken from pregnant rats which had been killed by cervical dislocation.

Postnatal day 28 rats were also used for comparison.

\section{Cell Culture Procedure}

In the experiments with embryos, we used the complex consisting of thyroid, parathyroid and ultimobranchial body as the thyroid gland, because it is very difficult to separate them each other.

The thyroid glands dissected out from 10 embryos were rinsed with Hanks' balanced salt solution (HBSS). The glands were then incubated with $0.5 \mathrm{ml}$ of HBSS containing $0.1 \%$ collagenase (Worthington, CLS II) and 1,000 units $/ \mathrm{ml}$ Dispase (Godo Shusei) at $37^{\circ} \mathrm{C}$ for $30 \mathrm{~min}$. At the end of the incubation, the tissue was mechanically disrupted by pipetting with a silicon-coated capillary pipette. The cell clusters that passed through a $100 \mu \mathrm{m}$ stainless sieve were washed twice with $2 \mathrm{ml}$ of the culture medium (described below) by gentle centrifugation $(100 \mathrm{~g}, 5 \mathrm{~min})$. The precipitated cells and cell clusters were resuspended in $200 \mu \mathrm{l}$ of the culture medium and this suspension was equally distributed onto 4 coverslips
(14 $\mathrm{mm}$ in diameter) in a 4-well multidish (Nunc). Consequently $50 \mu \mathrm{l}$ of the cell suspension was put into each well. The culture was incubated at $37^{\circ} \mathrm{C}$ in a humidified atmosphere of $5 \% \mathrm{CO}_{2}$ in air. After $2 \mathrm{~h}$, cells were examined for attachment to the coverslips and $0.45 \mathrm{ml}$ of the culture medium was added to each well. One half of the medium was changed every other day. All procedures described above were performed under sterile conditions. Preparation of thyroid glands from the embryos was always started at 1300 . At least five independent experiments were performed for each gestational age.

In 28-day-old rats, the thyroid glands were enzymatically dispersed according to the method described by Nitsch and Wollman (10), but with different culture medium. Dispersed cells were sieved, seeded and cultured as described above.

\section{Preparation of Rat Embryo Extract}

Heads and intestine were dissected out from G-16 embryos. The embryos without heads and intestine were homogenized in the equal volume of HBSS with a glass-Teflon homogenizer. The homogenate was centrifuged at $145,000 \mathrm{~g}$ for $30 \mathrm{~min}$. The resultant supernatant was treated with $0.5 \mathrm{mg} / \mathrm{ml}$ hyaluronidase (Sigma, Type I-S) at $25^{\circ} \mathrm{C}$ for $30 \mathrm{~min}$ to reduce the viscosity and then sterilized with a membrane filter cartridge $(0.22 \mu \mathrm{m}$, DISMIC25CS, Advantec Toyo).

\section{Culture Medium}

Dulbecco's modified Eagle medium (Gibco, No. 430-1600) was supplemented with 5\% fetal calf serum (Gibco) pretreated at $56^{\circ} \mathrm{C}$ for $30 \mathrm{~min}, 4 \%$ rat embryo extract, 50 units $/ \mathrm{ml}$ penicillin (Gibco) and $50 \mu \mathrm{g} / \mathrm{ml}$ streptomycin (Gibco).

\section{Fibronectin-Coating of Coverslips}

Rat plasma fibronectin was prepared by affinity chromatography on gelatin-agarose according to the methods of Miekka et al. (9). The coverslips were incubated with $20 \mu \mathrm{g} / \mathrm{ml}$ of fibronectin in HBSS for $2 \mathrm{~h}$. After removal of the fibronectin solution, the slips were airdried in a clean bench. 
Table 1 Crown-rump Length of the Rat Embryos Used in the Experiments

\begin{tabular}{cc}
\hline $\begin{array}{c}\text { Gestational age } \\
\text { of embryo (day) }\end{array}$ & $\begin{array}{c}\text { Crown-rump } \\
\text { length (mm) }\end{array}$ \\
\hline 14 & $9.5-11.5$ \\
15 & $11.5-13.0$ \\
16 & $14.0-16.0$ \\
17 & $17.0-19.0$ \\
18 & $20.0-23.0$ \\
\hline
\end{tabular}

\section{Immunocytochemical Procedures}

The fixative, detergent, bovine serum albumin (BSA) and antibodies were dissolved in phosphate-buffered saline (PBS) containing $140 \mathrm{mM} \mathrm{NaCl}, 2.5 \mathrm{mM} \mathrm{KCl}, 1.5 \mathrm{mM} \mathrm{KH}_{2} \mathrm{PO}_{4}$ and $8 \mathrm{mM} \mathrm{Na}_{2} \mathrm{HPO}_{4}$. The cells cultured on the coverslips were fixed with $4 \%$ paraformaldehyde (Taab) for $30 \mathrm{~min}$ and the fixed cells were then treated with $0.25 \%$ Triton X-100 (Wako) for $10 \mathrm{~min}$. In order to reduce nonspecific binding of the antibodies to the specimens, the cells were incubated with $10 \mathrm{mg} / \mathrm{ml}$ BSA (Sigma, Fraction $\mathrm{V}$ ) for
30 min. The specimens were then incubated with rabbit antiserum against human calcitonin (Miles, $1: 500$ ) or with rabbit antiserum against rat CGRP (Peninsula, $1: 200$ ) for $1 \mathrm{~h}$. The slips were rinsed in PBS and incubated with FITC-conjugated goat antiserum against rabbit $\mathrm{IgG}$ (Miles, $1: 200$ ). For negative controls, the primary antisera were replaced with normal rabbit serum (Miles). All the procedures described above were performed at room temperature.

\section{RESULTS}

Table 1 shows the crown-rump length of the embryos used in this study.

Following enzymatic dissociation, cells attached to fibronectin-coated glass substratum within $2 \mathrm{~h}$. In the culture derived from $\mathrm{G}$ 15 or later stages of embryos, the cellls flattened out and small groups of epithelium-like cells were found after 1 day of incubation. At day 2 in culture, the size of these groups increased, and usually form a confluent sheet (Fig. 1, B, C and D). On the contrary, typical
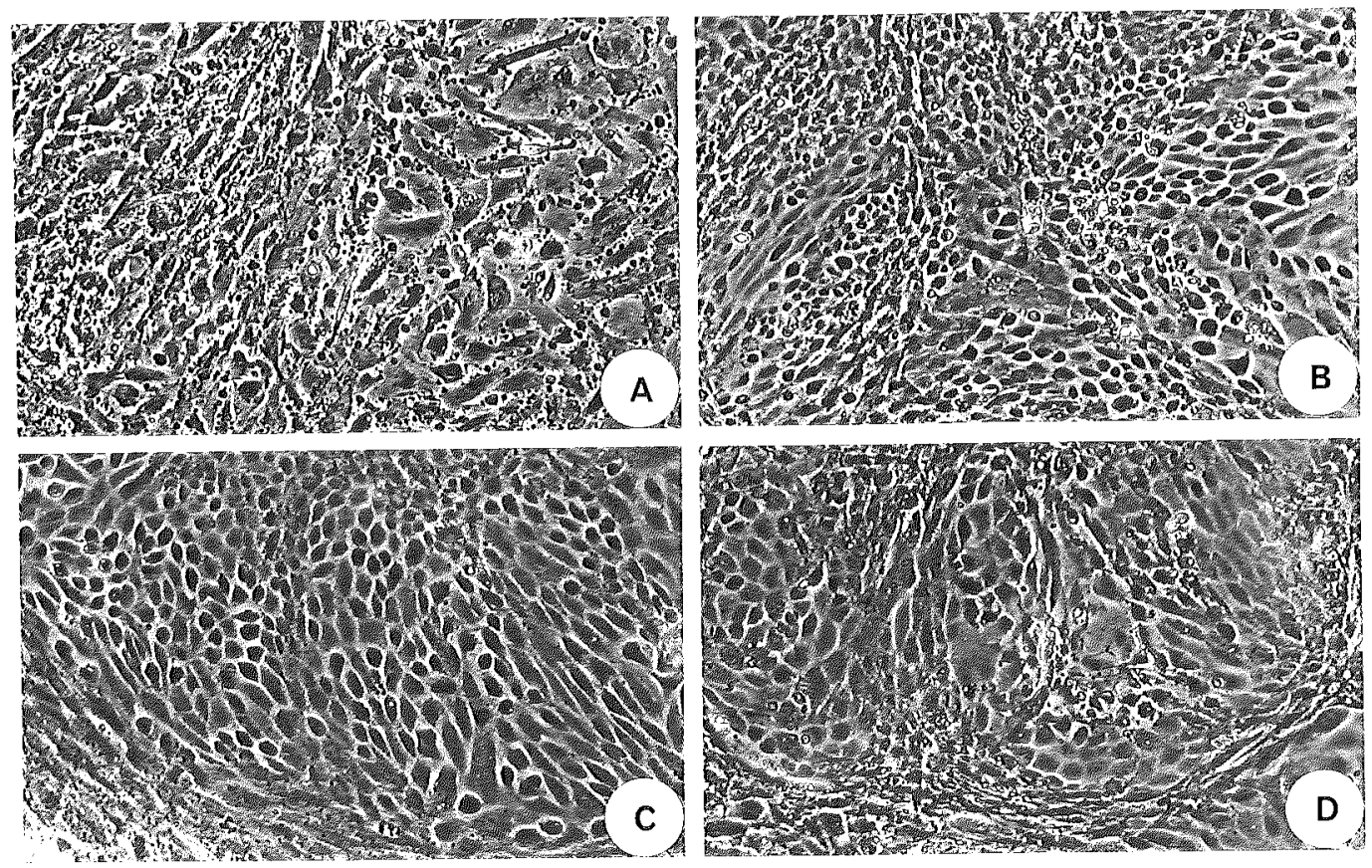

Fig. 1 Photomicrographs of the cultured thyroid cells as viewed through phase-contrast optics. The thyroid glands were taken from G-14 (A), G-15 (B) and G-17 (C) rat embryos, and from 28-day-old rats (D). The glands were enzymatically dispersed and cultured for 2 days. $\times 450$ 

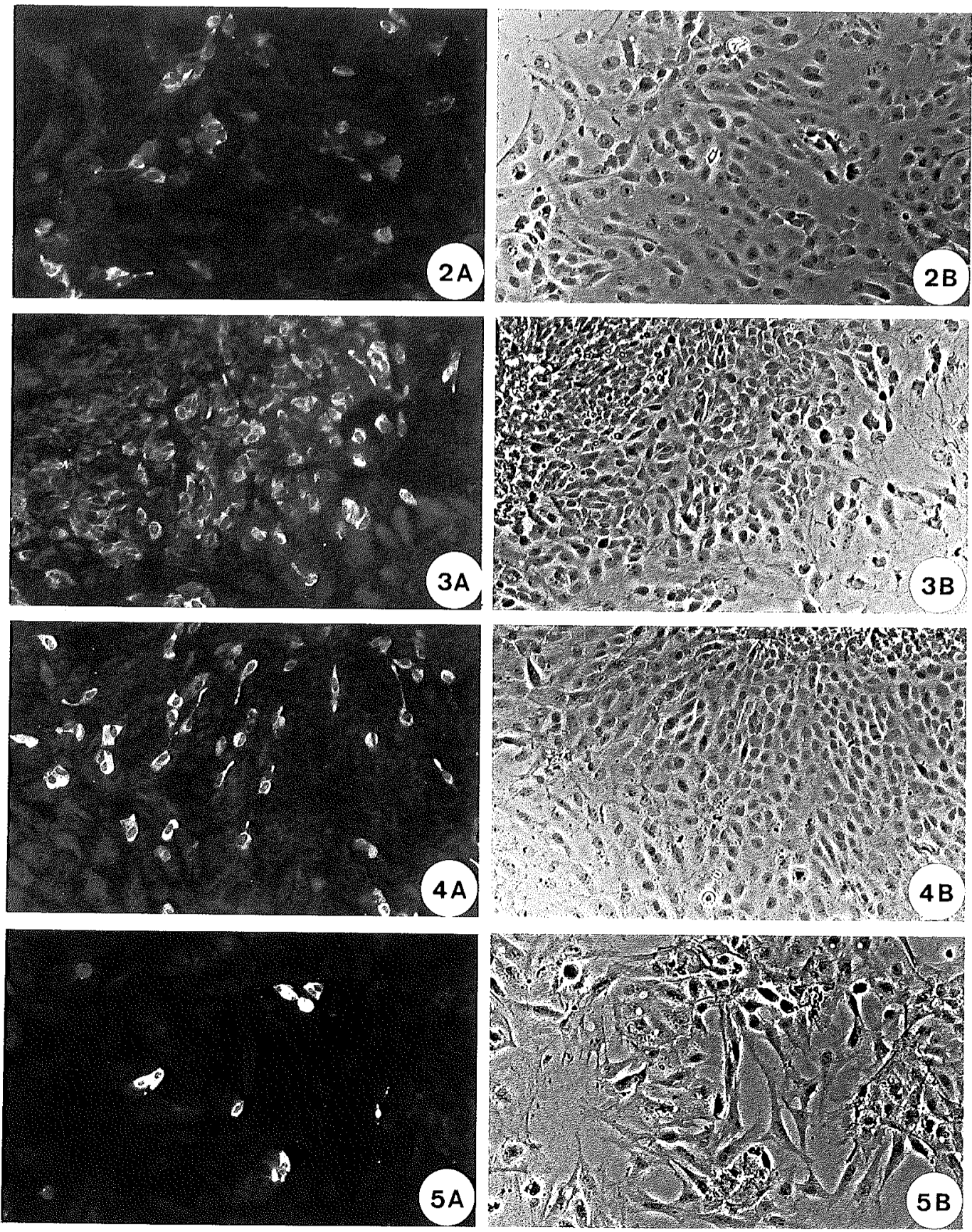

Figs. 2-5 Immunofluorescence photomicrographs showing calcitonin-immunoreactivity (A) and phasecontrast images of the same field (B). The cultures were derived from G-14 (Fig. 2), G-15 (Fig. 3) and G-17 (Fig. 4) rat embryos, and from 28-day-old rats (Fig. 5). After 2 days in culture, they were subjected to immunocytochemical experiments. Since the cells were treated with Triton X-100, the photographs in Bseries show lower contrast as compared with Fig. 1. $\times 450$ 

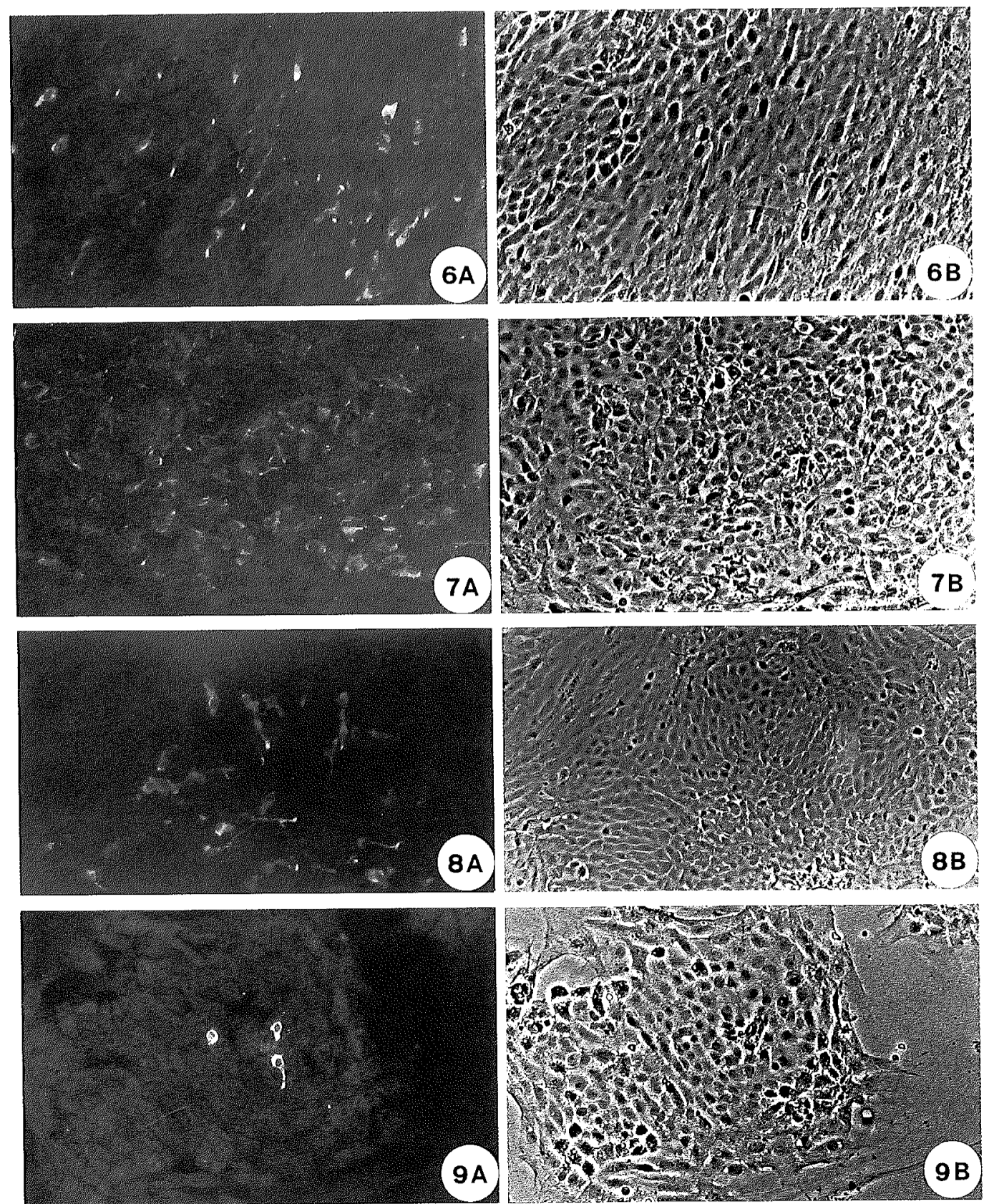

Figs. 6-9 Immunofluorescence photomicrographs showing the immunoreactivity for calcitonin generelated peptide (A) and phase-contrast images of the same freld (B). The cultures were derived from $G-14$ (Fig. 6), G-15 (Fig. 7) and G-17 (Fig. 8) rat embryos, and from 28-day-old rats (Fig. 9). After 2 days in culture, they were subjected to immunocytochemical experiments. Since the cells were treated with Triton X100 , the photographs in B-series show lower contrast as compared with Fig. $1 . \times 450$ 
image of epithelial cells was not found in the culture derived from G-14 embryos even after prolonged incubation period (Fig. 1A).

\section{Immunocytochemistry for Calcitonin}

Culture from G-14 embryos Seven independent experiments were carried out for the embryos of this age. At day 2 in culture, CTimmunoreactive cells were observed in 4 experiments (Fig. 2A). The cytoplasm of these cells was distinctly stained, whereas their nuclei were unreactive. Some of them possessed one or two cytoplasmic processes. When the incubation period was prolonged to 3 or 5 days, practically the same results were obtained.

Culture from $G$ - 15 embryos In all experiments, CT-immunoreactive cells were first appeared at day 2 in culture. They often appeared in clusters, in which almost all the cells exhibited CT-immunoreactivity (Fig. $3 \mathrm{~A})$.

Cultures from G-16, G-17 and G-18 embryos At day 2 in culture, a number of CT-immunoreactive cells were observed among epithelium-like cells (Fig. 4A). Homogeneous group of C-cells, as observed in the culture derived from G-15 embryos, was not seen for these ages. Instead, CT-immunoreactive cells showed rather dispersed distribution though small clusters were sometimes observed. Some of these cells projected cytoplasmic processes as long as $15 \mu \mathrm{m}$. The fluorescence intensity of CT- immunoreactive cells seemed to be higher than that seen in the culture from G-14 or G-15 embryos. Since practically the same results were obtained in the embryos of these ages, typical fluorescence image was shown in Fig. 4A.

Culture from 28-day-old rats At day 2 in culture, CT-immunoreactive cells were observed (Fig. 5A), Some of them formed a cell cluster composed of two or three cells. The intensity of the specific fluorescence was higher than that observed in any experiments described above.

\section{Immunocytochemistry for CGRP}

In each experiment, CGRP-immunoreactive cells appeared in the same manner as CTimmunoreactive cells. Briefly, CGRP-immu- noreactive cells did not always appear in the culture derived from G-14 embryos, but they did come out in the culture derived from embryos of G-15 or later stages at day 2 in culture (Figs. 6-8). The homogeneous groups of immunoreactive cells, as seen for CT-immunoreactive cells (Fig. 3A), were also observed at high incidence in the culture from G-15 embryos (Fig. 7A). CGRP-Immunoreactive cells were also found in the culture derived from 28-day-old rat (Fig. 9A). In all experiments, CGRP-immunoreactive cells seems to be less in number and exhibit weaker fluorescence than CT-immunoreactive cells.

In all experiments described above, specific immunoreactivity was never detected in the negative controls.

\section{DISCUSSION}

The experiments described here show that $\mathrm{C}$ cell precursors taken from the embryos as early as day 14 in gestation are able to differentiate to produce CT and CGRP in vitro even after enzymatically dispersed. Immunohistochemical study by Nitta et al. (11) revealed for rat embryo that CT- and CGRP-immunoreactive cells first appeared in the thyroid glands at gestational days 16 and 17 (17 and 18 in their definition) respectively. In our study, therefore, C-cell precursors must initiate production of CT and CGRP after they were removed to the culture. This was confirmed by the fact that cycloheximide $(1 \mu \mathrm{g} / \mathrm{ml})$ or puromycin $(1 \mu \mathrm{M})$ completely blocked the appearance of CT- and CGRP-immunoreactive cells in the culture from G-15 embryos (Nishiyama et al., in preparation).

During ontogeny of rodent thyroid C-cells, C-cell precursors exhibit multistep migration (3). Briefly, the neural crest cells at rhombencephalic level migrate to ventral portion of the fourth pharyngeal pouch, which forms the ultimobranchial body later. Then C-cell precursors in the ultimobranchial body migrate into the thyroid glands, and eventually occupy their definitive, parafollicular locality. The homogeneous aggregation of numerous CTand CGRP-immunoreactive cells, as shown in Figs. $3 \mathrm{~A}$ and $7 \mathrm{~A}$, may result from incomplete cell dissociation of the ultimobranchial body at these stages. In agreement with this speculation, C-cells showed rather scattering distribu- 
tion in the culture derived from G-17 or later stages of embryos, when the ultimobranchial body cells have invaded to the thyroid glands.

In this study, we used thyroid cells and cell clusters passed through $100 \mu \mathrm{m}$-opening sieve for the culture. When the thyroid glands were completely dispersed and seeded onto the substratum, almost no C-cell appeared in the culture regardless of the gestational age of the embryos. Moreover, we could not find a single $\mathrm{C}$-cell to adhere directly, independently of epithelium-like cells, to the substratum throughout the experiments. These results lead us to speculate that C-cells are not capable of adhering directly to the fibronectin-coated glass surface. Our preliminary data suggested that C-cells also failed to adhere directly to the glass surface coated by laminin, collagen (type I) or poly-D-lysine. To simplify the experimental system, we have to find the substratum to which C-cells adhere directly.

C-cells produce biologically active peptides besides CT and CGRP such as somatostatin (12), gastrin/cholecystokinin-like substance (7) and, in the C-cell line derived from medullary thyroid carcinoma, neurotensin (17). We selected CT and CGRP as the markers of Ccell differentiation because the former is a representative, well-known product of C-cells and the latter was the product by alternative splicing of RNA transcripts from the gene common with CT (2). In the experiments described here, CT- and CGRP-immunoreactive cells appeared in the same manner as to the ontogenetic aspect. But we have not examined whether or not the identical C-cells coproduce both peptides. Previous studies clearly demonstrated that almost all C-cells exhibit an intense immunoreactivity for CGRP in 14day-old (11) and adult rats $(4,11)$. The coexistence of CT and CGRP has been also ascertained at the level of mature mRNA transcripts encoding either peptide (15). In rat embryos, however, coexistence of these peptides in C-cells has not yet examined. It seems to be of great interest whether CT and CGRP coexist in rat embryonic $\mathrm{C}$-cells since it is likely that $\mathrm{C}$-cells change their peptide repertoire during ontogeny. This problem is now under investigation in our laboratory.

In conclusion; we have succeeded in establishing the culture condition under which $\mathrm{C}$ cell precursors taken from rat embryos become to express CT and/or CGRP, though the problem of C-cell adhesion to the substratum is still unsettled. The results give us fundamental information helpful for elucidating in vitro the ontogenetic mechanism of the $\mathrm{C}$ cells.

We would like to thank Dr Toshiko Takaoka, Dr Takayuki Hasegawa and Dr Noriko Usui for their technical advice. This work was supported in part by a grant to T. Fujii from The Mitsubishi Foundation.

\section{Received for publication 4 August 1988}

\section{REFERENCES}

1. Alumets J., Håkanson R., Lundquist G., Sundler F. and Thorell J. (1980) Ontogeny and ultrastructure of somatostatin and calcitonin cells in the thyroid gland of the rat. Cell Tissue Res. 206, 193-201

2. Amara S. G., Jonas V., Rosenfeld M. G., OnG E. S. and Evans R. M. (1982) Alternative RNA processing in calcitonin gene expression generates mRNAs encoding different polypeptide products. Nature 298, 240-244

3. Fontaine J. (1979) Multistep migration of calcitonin cell precursors during ontogeny of the mouse pharynx. Gen. Comp. Endocrinol. 37, 8192

4. KAMEDA Y. (1987) Localization of inmunoreactive calcitonin gene-related peptide in thyroid $\mathrm{C}$ cells from various mammalian species. Anat. Rec. 219, 204-212

5. KameDa Y. (1988) Ontogeny of immunoreactive calcitonin gene-related peptide in thyroid $\mathrm{C}$ cells from dogs, rabbits, and guinea pigs. Anat. Rec. 220, 76-86

6. Kameda Y., Oyama H., Endoh M. and Horino M. (1982) Somatostatin immunoreactive C cells in thyroid glands from various mammalian species. Anat. Rec. 204, 161-170

7. LaRsson L.-I. (1985) Differential changes in calcitonin, somatostatin and gastrin/cholecystokinin-like immunoreactivities in rat thyroid parafollicular cells during ontogeny. Histochemistry 82, 121-130

8. Le Douarin N. et Le Lièvre C. (1970) Démonstration de l'origine neurale des cellules à calcitonine du corps ultimobranchial chez l'embryon de Poulet. C. R. Acad. Sci. (Paris) 270, 2857-2860

9. Miekka S. I., Ingham K. C. and Menache D. (1982) Rapid methods for isolation of human plasma fibronectin. Thromb. Res. 27, 1-14

10. Nitsch L. and Wollman S. H. (1980) Suspension culture of separated follicles consisting of 
differentiated thyroid epithelial cells. Proc. Natl. Acad. Sci. USA 77, 472-476

11. NitTa K., Kito S., Kubota Y., Girgis S. I., Hillyard C. J., MacIntyre I, and InaGaki S. (1986) Ontogeny of calcitonin gene-related peptide and calcitonin in the rat thyroid. Histochemistry 84, 139-143

12. Noorden S. V., Polak J. M. and Pearse A. G. E. (1977) Single cellular origin of somatostatin and calcitonin in the rat thyroid gland. Histochemistry 53, 243-247

13. Pearse A. G. E. (1969) The cytochemistry and ultrastructure of polypeptide hormone-producing cells of the APUD series and the embryologic, physiologic and pathologic implications of the concept. J. Histochem. Cytochem. 17, 303-313

14. Pearse A. G. E. and Polak J. M. (1971) Cyto- chemical evidence for the neural crest origin of mammalian ultimobranchial C Cells. Histochemie 27, 96-102

15. Sabate M. I., Stolarsky L. S., Polak J. M., Bloom S. R., Varndell I. M., Ghatei M. A., Evans R. M. and Rosenfeld M. G. (1985) Regulation of neuroendocrine gene expression by alternative RNA processing. J. Biol. Chem. 260, 2589-2592

16. Titlbach M., VelickÝ J. and Lhotová H. (1987) Prenatal development of the cat thyroid: immunohistochemical demonstration of calcitonin in the "C" cells. Anat. Embryol. 177, 51-54

17. ZeytinoǦlu F. N., Brazeau P. and Culkin M. K. (1983) Regulation of neurotensin secretion in mammalian $\mathrm{C}$ cell lines: Potassium and norepinephrine affect the rapid release of the peptide. Regul. Pept. 6, 155-162 